\title{
RESOURCE-BASED STRATEGIES IN LAW AND POSITIVE POLITICAL THEORY: COST-BENEFIT ANALYSIS AND THE LIKE
}

\author{
EMERSON H. TILLER ${ }^{\dagger}$
}

\section{INTRODUCTION}

In addition to the good that often inures to the public from the use of cost-benefit analysis and other like instruments by policymakers, a more insidious nature to these decision-making instruments exists-that nature is the ideological, often partisan, control of public policy. The political control exercised through cost-benefit analysis and similar strategy-laden instruments allows one or more policymakers to force a competing policymaker to expend valuable, and limited, resources. Indeed, the imposition of these instruments by a controlling political coalition can compromise greatly, or even prevent, policies desired by a competing policymaking institution. Resource-based strategies are available to Congress through legislation and agency design, to the President through executive orders, and to the judiciary through doctrine and other instruments of legal reasoning. Such strategies can be exercised horizontally through separated-powers games or vertically (upstream and downstream) in court-agency hierarchies.

While the notion of decision costs and limited resources as constraints on law and policymaking have found their way into recent legal analyses, 1 few scholars have described the broader political control

\footnotetext{
${ }^{\dagger}$ Visiting Associate Professor of Business, University of California, Berkeley; Associate Professor of Business, University of Texas at Austin.

1 A few recent works incorporate notions of resources and decision costs. See Bradford R. Clark, Separation of Powers as a Safeguard of Federalism, 79 TEX. L. REv. 1321, 1427 n.661 (2001) (warning that "if carried too far, clear statement rules could increase the decision costs of legislation beyond those established by federal lawmaking procedures"); Elizabeth Garrett \& Adrian Vermeule, Institutional Design of a Thayerian Congress, 50 DUKE L.J. 1277, 1290 (2001) ("The most striking fact about Congress is its severely constricted agenda. Despite the enormous growth of congressional staff and the refined specialization of its internal structure, Congress faces tight deliberative constraints of time and information." (footnotes omitted)); Neal Kumar Katyal, Legislative Constitutional Interpretation, 50 DUKE L.J. 1335, 1390 (2001) (“[C]ourt decisions that explicitly state that the opinion's logic and rules are not binding in future cases should be disfavored because they minimize decision costs and permit party bias to creep into
} 
strategies available to institutions using a resource-based approach. Positive Political Theory (PPT) offers a framework for thinking about resource-based strategies, and the implications that result are profound. Below, I solidify the current understanding of resource-based strategies from the PPT approach. I then incorporate recent insights from Jason Johnston and others to round out a more complete PPT of resource-based strategies. I conclude with suggestions for further research and improvements in resource-based PPT.

\section{Positive Political TheORY ANd Resource-BASEd Strategies}

In analyzing public policies, the various models and theories that pose as $\mathrm{PPT}^{2}$ typically invite an analysis of: (1) the partisan shifts and alignments among political and judicial institutions (usually through elections or appointments); $;^{3}$ (2) the rules of the game for interaction among policymakers (such as judicial review, bicameralism, and congressional committee systems) $;^{4}$ and (3) the decision resources of the

the judiciary."); John F. Manning, Textualism and the Equity of the Statute, 101 CoLuM. L. REV. 1, 74-75 (2001) (explaining how bicameralism increases decision costs in a way that reduces the ability of political factions to pass legislation securing private advantage); Cass R. Sunstein, Nondelegation Canons, 67 U. CHI. L.. REV. 315, 342 (2000) ("[A] simple version of the Chevron principle; allowing agencies to interpret ambiguous provisions, promises to hold down decision costs ... in the sense that people will know that where there is ambiguity, the agency will prevail."); Ariel Waldman, Allocating the Burden of Proof in Rule 60(b)(4) Motions to Vacate a Default Judgment for Lack of Jurisdiction, 68 U. CHI. L. REV. 521, 539 (2001) ("While courts can engage in line-drawing-they do in many areas of the law-the decision costs may be more significant where such an exercise is mandated. Such proceedings should not consume courts' finite resources." (footnotes omitted)).

${ }^{2}$ For a general introduction to law and PPT, see Symposium, Positive Political Theory and Public Law, 80 GEO. L.J. 457 (1992).

${ }^{3}$ See, e.g., John M. de Figueiredo et al., Congress and the Political Expansion of the U.S. District Courts, 2 AM. L. \& ECON. REV. 107, 123 (2000) (concluding that partisan alignment among the House, Senate, and President is a dominant factor explaining the timing of expansion of the number of federal district court judgeships); John M. de Figueiredo \& Emerson H. Tiller, Congressional Control of the Courts: A Theoretical and Empirical Analysis of Expansion of the Federal Judiciary, 39 J.L. \& ECON. 435, 438 (1996) (explaining the expansion of the federal judiciary as a function of partisan alignment among the House, Senate, and President); Rafael Gely \& Pablo T. Spiller, A Rational Choice Theory of Supreme Court Statutory Decisions with Applications to the State Farm and Grove City Cases, 6 J.L. ECON. \& ORG. 263, 266 (1990) (presenting a "model of the Supreme Court, which in principle resembles an activist Court, [that] predicts that the Court will play different roles depending on the composition of (and changes in) Congress").

See, e.g., William N. Eskridge, Jr., \& John Ferejohn, The Article I, Section 7 Game, 80 GEO. L.J. 523, 528-33 (1992) (using PPT to explain the role of bicameralism and legislative vetoes); Barry R. Weingast \& William J. Marshall, The Industrial Organization of 
various political institutions (agency budget or judicial time and staffing, for example). ${ }^{5}$ For the most part, PPT has attempted to explain policy change as some combination of these factors, with the role of decision resources playing an increasingly prominent role in the literature. ${ }^{6}$

PPT works from two levels of analysis-strategic action and strategic design. Strategic action analysis takes the rules of the game as given and predicts the behavior of the players. That predicted behavior often changes with partisan shifts in the institutions themselves. The action is often the strategic location of policy by an initiating actor within a policy space accessible to various other policymaking institutions, but unlikely to be overruled by these other players given the policy preference alignments among the various institutions. For example, a court or agency may choose a policy that would be unacceptable to the median member of Congress, but which may be safe from congressional override because the congressional committee with policy jurisdiction favors that policy over the likely alternative desired by the median congressional member and, thus, would not let an override bill reach the floor for a vote. ${ }^{7}$ Strategic action analysis is typically informative in looking at particular regulations, legal cases, or pieces of legislation. $^{8}$

By contrast, the main focus of strategic design analysis is on how an institution is constructed to foster a series of policy outcomes con-

Congress; or, Why Legislatures, Like Firms, Are Not Organized as Markets, 96 J. POL. ECON. 132, 148-60 (1988) (using PPT to explain the interaction of committee systems with the full chamber in Congress).

${ }^{5}$ See, e.g., Pablo T. Spiller, Agency Discretion Under Judicial Review, 16 MATHEMATICAL \& COMPUTER MODELLING 185, 199 (1992) (developing "the role of decision costs in both increasing agency discretion as well as in generating judicial reversal of administrative agency policies").

${ }^{6}$ A few papers have even explored the normative dimensions of reform from the PPT perspective. See, e.g., Daniel B. Rodriguez, The Positive Political Dimensions of Regulatory Reform, 72 WASH. U. L.Q. 1, 8, 110-49 (1994) (considering "the applications of positive political theory to some normative issues in statutory interpretation and administrative law"); Emerson H. Tiller \& Frank B. Cross, A Modest Proposal for Improving American Justice, 99 CoLUM. L. REV. 215, 215-16 (1999) (calling for partisan-diverse appellate court panels to alleviate the risk of political manipulation of sound legal doctrines).

${ }^{7}$ See John Ferejohn \& Charles Shipan, Congressional Influence on Bureaucracy, 6 J.L. ECON. \& ORG. 1 (1990) (Special Issue) (explaining agency strategies from a PPT perspective incorporating judicial and executive influences).

${ }^{8}$ See, e.g., Pablo T. Spiller \& Matthew L. Spitzer, Judicial Choice of Legal Doctrines, 8 J.L. ECON. \& ORG. 8, 10-11 (1992) (using PPT to suggest why the Supreme Court will use constitutional rather than statutory interpretation in a strategic game with Congress). 
sistent with the policy preferences of the designer. ${ }^{9}$ Individual legal cases or pieces of legislation are not the focal point, although ultimately they may be explained in part by the change in the design of a policy institution. Instead of taking the rules of the game as given, strategic design analysis explains why the rules of the game get changed, and how those changes benefit particular political interests. $^{10}$ The strategic design explanations routinely are rooted in an understanding of the partisan alignments among the various institutions-with one or two institutions attempting to control a politically unaligned competing institution."

Whether it be strategic action or strategic design analysis, the role of decision costs generally is implicated as it fosters policy control. This is especially true when institutions foist instruments such as costbenefit analysis and the like upon competing institutions. Consider below the implications of resource-based strategies from "downstream" and "upstream" PPT frameworks.

9 See, e.g., Mathew D. McCubbins et al., Administrative Procedures as Instruments of Political Control, 3 J.L. ECON. \& ORG. 243, 273-74 (1987) [hereinafter McCubbins et al., Administrative Procedures] (explaining that elected politicians design administrative procedures in addition to, or instead of, monitoring agency activities and providing sanctions to achieve bureaucratic compliance); Mathew D. McCubbins et al., Structure and Process, Politics and Policy: Administrative Arrangements and the Political Control of Agencies, 75 VA. L. REV. 431, 432-33 (1989) [hereinafter McCubbins et al., Structure and Process] (discussing legislative design of administrative procedures to control agency decision making); see also Murray J. Horn \& Kenneth A. Shepsle, Commentary on "Administrative Arrangements and the Political Control of Agencies": Administrative Process and Organizational Form as Legislative Responses to Agency Costs, 75 VA. L. REV. 499, 499 (1989) (employing the "assumption of intelligent foresight" to conclude that elected politicians in creating agencies devise initial enactments that will protect against the future influences of bureaucrats and subsequent political coalitions); Jonathan R. Macey, Separated Powers and Positive Political Theory: The Tug of War over Administrative Agencies, 80 GEO. L.J. 671, 673 (1992) (outlining the argument that “Congress's ability to design and structure an agency will 'hardwire' the agency to generate decisions that reflect the original understanding of the enacting coalition").

${ }^{10}$ See, e.g., Linda R. Cohen \& Matthew L. Spitzer, Judicial Deference to Agency Action: A Rational Choice Theory and an Empirical Test, 69 S. CAL. L. REV. 431, 474-76 (1996) (finding that the Supreme Court discriminately endorses judicial deference where it supports policy outcomes to Court's liking); McCubbins et al., Structure and Process, supra note 9, at 440 (explaining the "fundamental ways in which an agency's structure ... can influence its policy decisions").

$"$ See, e.g., Linda R. Cohen \& Matthew L. Spitzer, Solving the Chevron Puzzle, Law \& CONTEMP. ProBs., Spring 1994, at 65, 68 (concluding that the Supreme Court used legal doctrine to afford administrative agencies greater or lesser discretion, based on the changing conservative and liberal nature of agencies, in the 1980s); de Figueiredo \& Tiller, supra note 3, at 436 (discussing congressional pursuit of political aims by "control[ling] the federal judiciary through structural design"). 


\section{DOWNSTREAM ResourCE-BASEd STRATEgIES}

PPT has said much about principal-agent relationships and political control. Congressional control of agencies and higher court control of lower courts are two standout examples in the literature. Both strategic action and strategic design principal-agent models have incorporated the notion of cost-imposition as part of the control mechanisms used by the principal over the agent.

\section{A. Congress-Agency}

Pablo Spiller and I recently developed a principal-agent model of congressional control over agencies that focused on resource-based strategies. ${ }^{12}$ We modeled the ability of Congress to control regulatory policy by structuring agencies with varying degrees of decision costs based on their alignment with Congress. ${ }^{13}$ We applied our model to the proposed Comprehensive Regulatory Reform Act of 1995, sponsored by then Senate Majority Leader Robert Dole, as an example of how Congress could create decision costs for agencies in order to control their output. ${ }^{14}$ The political context of that legislative proposal was well documented:

In short, the election of a Republican majority to Congress in 1994 brought about efforts to limit Clinton-controlled agencies that were issuing, or anticipated to issue, liberal regulatory policies. Dole's bill, had it been enacted, would have imposed significant decision costs on agencies attempting to promulgate major new rules. Among other things, the bill required that agencies conduct cost-benefit analyses to demonstrate that the benefits of imposing a new regulation would outweigh the costs. The Dole bill provided that, except in the very rare cases where legislation specifically ruled them out, government agencies would have to justify regulations by using strict, monetized cost-benefit analyses. In the case of employee safety standards, for example, Occupational Safety and Health Administration (OSHA) would have to determine whether the benefits of eliminating a work hazard outweighed the costs for the employer or the general public. Because many public health and environmental threats are difficult to quantify, the effect would have been to substantially delay, if not eliminate, agency action on many public policy objectives. Critics pointed out that the measure would be expensive and bureaucratic and would require cumbersome and costly additional stud-

${ }^{12}$ Pablo T. Spiller \& Emerson H. Tiller, Decision Costs and the Strategic Design of Administrative Process and Judicial Review, 26 J. LEGAL STUD. 347 (1997).

${ }^{13}$ Id. at 347-48.

${ }^{14}$ See $i d$. at 361-63 for a more detailed examination of the Comprehensive Regulatory Reform Act of 1995 through the PPT decision cost framework suggested here. 
ies before new regulations could be imposed. Moreover, once an agency demonstrated cost effectiveness, it would also be required to show that the proposed regulation is the least cost means of achieving the desired result. This would reduce the number of agency initiatives and make some policy changes too costly to attempt. ${ }^{15}$

This resource-based strategy of cost-benefit analysis is, of course, dependent upon a judiciary that will enforce the decision costs through thorough review. ${ }^{16}$ We modeled the courts as policy seekers, ${ }^{17}$ meaning that judicial enforcement was greatly dependent upon a politically willing judiciary. Thus, political alignment between Congress and the judiciary was a critical component of the resource-based strategy. ${ }^{18}$

We also noted that Congress has the choice to focus its response on a single agency, or it may take "a broader stroke at control."19 Congress may, for example, find that most agencies are in line with congressional will. In such a case, attention to individual wayward agencies (or policies from them) would be more efficient than broad sweeping proposals that would impose costs on all agencies. When, however, the political control of Congress is different from that of agencies (as when the President and Congress are of different parties) broad structural mechanisms affecting all agencies, such as a costbenefit analysis requirement for all agency rules, may provide Congress with more efficient control.

\section{.B. Courts-Agency}

Resource-based strategies that more directly emanate from the courts, as principals, in controlling agency behavior also can be examined through the PPT lens. Consider the ability of a federal court to control agency policy. Courts have several instruments with which they can review and reverse administrative agency decisions. Some instruments focus on the agency's interpretation of its governing stat-

${ }^{15} I d$. at 361 . For a different conclusion about the effect of cost-benefit regulation, see Eric A. Posner, Controlling Agencies with Cost-Benefit Analysis: A Positive Political Theory Perspective, 68 U. CHI. L. REV. 1137, 1169-72 (2001) (concluding that the imposition of cost-benefit analysis increases, rather than decreases, the amount of regulation because it allows Congress to trust agencies more than when agencies have an informational advantage).

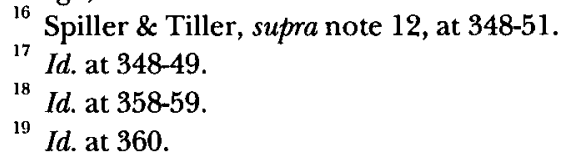


utes (statutory interpretation) while others relate to the agency's process of making decisions (process review). In statutory interpretation, the court asks itself whether the agency, in setting a particular policy, correctly interpreted specific words of the statute as intended by Congress. If not, then the policy is void and agency enforcement is precluded. With process review the court may determine whether the agency adequately considered all the relevant evidence or regulatory alternatives presented by interested parties in the agency's decisionmaking processes, made a decision logically consistent with the evidence, fully explained the basis of its decision, or made a decision consistent with previous agency decisions so as not to be "arbitrary and capricious." ${ }^{20}$ In short, the essence of this instrument is to attack the reasoning processes of the regulator and force it to spend more of its resources (whether through more extensive studies or more detailed reasoning of policy choices) to achieve its desired policy objective. If a court can demand that an agency spend more of its limited resources on process, the agency will promulgate fewer policies, or at least fewer court-disfavored policies.

The interaction can be viewed from both the strategic action and strategic design levels. At the strategic action level, we see a lower court's ability in an individual case to require more reasoning and process from the agency as a resource barrier for the agency in moving a particular policy beyond the policy range preferred by the court. From the design level, we can look up the judicial hierarchy and view Supreme Court administrative law doctrines as a constraining or liberating force upon lower courts' use of process strategies. In particular, the high Court may establish a deference doctrine (a design strategy), where lower courts are strictly limited in their ability to interfere with agency decision making (a strategic action), or the Supreme Court can issue a nondeference doctrine, where lower courts have greater reign in scrutinizing agency decision making. In a recent article, I modeled the D.C. Circuit's resource-based control over the Federal Energy Regulatory Commission (FERC) as it was affected by the Supreme Court's administrative law doctrine:

4.2.2 Shifting Administrative Law Doctrines. Shortly after FERC made its [deregulatory] policy, the Supreme Court, in reviewing an unrelated case of administrative deregulation, endorsed a nondeference doctrine (N) for judicial review of administrative deregulation. This raised the level of process that the appellate courts reviewing administrative deregulation could demand .... Oil shippers immediately appealed

${ }^{20}$ Administrative Procedure Act, 5 U.S.C. $\$ 706(2)$ (A) (1994). 
FERC's new policy to the D.C. Circuit. That court, relying on the Supreme Court's endorsement of a nondeference doctrine for administrative deregulation, held that FERC had contravened its responsibility to ensure that oil pipeline rates were "just and reasonable." The D.C. Circuit panel (2 Democrats and 1 Republican) agreed with the shippers' claim that FERC, in changing the regulatory scheme from the traditional fair value methodology, had not undertaken all the analytic processes required by the APA. More specifically, [and citing the State Farm decision] the D.C. Circuit concluded that FERC had not carried out an in-depth analysis to demonstrate that market forces could be relied upon to keep prices at reasonable levels throughout the pipeline industry. The court held that any departure from the previous rate-making method must be made, if at all, only when the new factors are clearly identified and a reasoned explanation given for how such factors justify the resulting rates. Furthermore, the court held that FERC had not adequately considered the alternative methodologies offered to the agency during its decision processes. In short, the court faulted FERC's reasoning processes. Concluding that FERC's decision was "arbitrary and capricious" under the APA, the court remanded the rule back to the commission for reconsideration (and even suggested that a methodology using some cost-based factors would be preferred). ${ }^{21}$

Analyses by other commentators likewise support the view that judicially imposed process requirements can be used as a method of political control over agencies. Professors Pierce and McGarity, for example, each analyzed the effects of judicially imposed process requirements on agency decision making and both concluded that such requirements had essentially "ossified" the agency rulemaking process. $^{22}$ More specifically, the ability of courts to scour the rulemaking record to find flaws in the analyses of regulators (of which there will always be some) allows judges to impose process requirements that can take up to a decade for regulators, with their limited resources, to subsequently accomplish. What often results, McGarity

${ }^{21}$ Emerson H. Tiller, Controlling Policy by Controlling Process: Judicial Influence on Regulatory Decision Making, 14 J.L. ECON. \& ORG. 114, 126-27 (1998) (citations omitted). While the article did not examine the Supreme Court's doctrinal shift as design strategy in particular, such work has been done by Cohen and Spitzer. Cohen \& Spitzer, supra note 10, at 77; Cohen \& Spitzer, supra note 11, at 431.

${ }^{22}$ See Thomas O. McGarity, Some Thoughts on Deossifying the Rulemaking Process, 41 DUKE L.J. 1385, 1387 (1992) ("Although no detailed empirical studies exist on the comparative burdensomeness of informal rulemaking and alternative regulatory vehicles, it is difficult to disagree with the conclusion that it is much harder for an agency to promulgate a rule now than it was twenty years ago."); Richard J. Pierce, Jr., Two Problems in Administrative Law: Political Polarity on the District of Columbia Circuit and Judicial Deterrence of Agency Rulemaking, 1988 DUKE L.J. 300, 327 ("The appellate courts have made the process of policymaking by rulemaking extraordinarily expensive and time consuming by imposing unrealistic requirements on agencies."). 
concludes, is the abandonment of the policy by the agency, some modification of the policy goal, or a less clearly stated policy accomplished through more indirect efforts of regulators. ${ }^{23}$ Pierce goes further to find that process-based reversals of agency policy are largely influenced by the political affiliation of appellate court judges and the agency policy they are reviewing. ${ }^{24}$ In a small set of cases he surveyed, Pierce found that Democratic appellate court judges were more likely to reverse an agency in favor of individuals, while Republicans were more likely to reverse in favor of business. ${ }^{25}$

\section{UPSTREAM RESOURCE-BASED STRATEGIES}

The selection of the various decision instruments by agencies and courts (for example, rulemaking and adjudication for agencies, and statutory interpretation and reasoning process review for courts) can also be modeled as "upstream" strategic choices that impact the resources of lower and higher courts with review power, especially when those reviewing institutions hold opposing policy preferences. ${ }^{26}$ The ability of agencies and courts to manipulate the instruments of decision making, rather than merely selecting policy choices, can allow them to insulate their policy choices from higher-level review. ${ }^{27}$ This "upstream" theory is based on the notion that decision instruments pose differential costs and payoffs for both the initiating and reviewing actors, each of whom have resource constraints. Because the initiating actor has a choice among instruments to make a decision (and to which a higher-level reviewing actor is tied) the initiating actor can manipulate decision costs in a strategic fashion (choosing higher review cost instruments to discourage higher level review, in particular).

23 McGarity, supra note 22, at 1436.

${ }^{24}$ Pierce, supra note 22, at 303.

${ }^{25} I d$. at 305.

${ }^{20}$ See generally Peter L. Strauss, One Hundred Fifty Cases per Year: Some Implications of the Supreme Court's Limited Resources for Judicial Review of Agency Action, 87 COLUM. L. REv. 1093, 1095 (1987) (observing that "the Court's awareness [of] how infrequently it is able to review lower court decisions has led it to be tolerant, even approving, of lower court and party indiscipline in relation to existing law").

${ }^{27}$ See Emerson H. Tiller \& Pablo T. Spiller, Strategic Instruments: Legal Structure and Political Games in Administrative Law, 15 J.L. ECON. \& ORG. 349, 350-51 (1999) (discussing how and why agencies "choose one instrument . . over another" and arguing that one consideration is avoiding reversal by an appellate court). 


\section{A. Agency-Court}

More concretely, suppose an agency wishes to move policy, but suspects that a reviewing court does not favor the policy. Should the agency choose rulemaking, a court in one fell swoop could kill the policy by reversing the rulemaking. Thus the most effective resourcebased strategy for the agency may be to move policy through a series of adjudications that would impose greater review costs on the courts than would rulemaking. ${ }^{28}$ In this fashion, the agency could limit the court's ability to control it because: (1) the agency could treat any single reversal as limited to that individual agency adjudication; and, correspondingly, (2) the court would need to reverse a series of individual adjudications to ultimately rein in the agency. Such would impose greater review costs on the courts, thereby encouraging them to take the less costly action of deferring rather than investigating and reversing.

\section{B. Lower Court-Higher Court}

Similarly, a lower court wishing to reverse an agency policy might choose strategically between reversal instruments-statutory interpretation versus reasoned process-to reverse the agency and insulate its own decision against higher courts that may favor the agency policy. A recent PPT model considered such a game and posited that lower courts would choose reasoning process over mere statutory interpretation to reverse agencies when: (1) the agency issued a policy inconsistent with the lower court's preferences, and (2) a higher court had policy preferences consistent with the agency. ${ }^{29}$ The logic of the model was that a reasoning process reversal of agency policy by a lower court, which is often a fact-based enterprise, is relatively more costly (effort per policy impact) for higher courts to review than are statutory interpretation reversals. ${ }^{30}$ Thus, greater deference from the higher courts would result if they were faced with reviewing a lower court process reversal of an agency. ${ }^{31}$

This model finds some support from recent empirical studies.

\footnotetext{
${ }^{28}$ In actuality, this is a much more complex calculation, as the agency would also need to consider its own increased decision-making costs associated with using an adjudication strategy. Such a tradeoff may not be feasible if the agency is severely resource constrained.

${ }^{29}$ Tiller \& Spiller, supra note 27, at 363-65.

so Id. at 364 .

${ }^{31} I d$.
} 
Consider the findings of Professor Revesz. ${ }^{32}$ In a study of the D.C. Circuit's review of EPA policy decisions, Revesz found support for the proposition that judicial ideology (as measured by political party affiliation) influenced decision making and that it was more prevalent in process challenges to the EPA than in statutory interpretation challenges. ${ }^{93}$ More specifically, Revesz tested whether the D.C. Circuit was engaged in "selective deference" (politics) or "consistent deference" (sincere application of doctrine). ${ }^{34} \mathrm{He}$ also tested whether selective deference was more pronounced with respect to process challenges than statutory interpretation challenges. ${ }^{95}$ In the period from the mid-1980s through the mid-1990s, Revesz found support for the claim that judges engaged in selective deference. ${ }^{36}$ Specifically, he found that Republican judges were less likely than Democratic judges to defer to the EPA when industry challenged EPA policy and that Democrats were less likely to defer when environmentalists challenged the EPA. $^{37}$ Revesz also found that selective deference was more likely to occur in process challenges than in statutory interpretation challenges. $^{38}$ The results were statistically significant. ${ }^{39}$

A more recent study, which examines whether appellate courts strategically select among the grounds for reversal, provides similar support. $^{40}$ In particular, Professor Smith and I considered whether judicial panels of one political party were more likely than panels of the other party to choose process over statutory interpretation as a means to reverse the EPA in favor of the panels' preferences (as measured by party affiliation, with Democrats being pro-environment and Republicans being pro-business). The logic of the study rested on the contention that process review was relatively more costly (in terms of policy impact per review effort) for higher courts (circuit courts en banc and Supreme Court) to review than would be statutory interpretation. $^{41}$ Consequently resource-constrained higher courts would not

${ }^{32}$ Richard L. Revesz, Environmental Regulation, Ideology, and the D.C. Circuit, 83 VA. L. REV. 1717 (1997).

Id. at 1766-67.

${ }^{34}$ Id. at 1728 .

${ }^{35}$ Id. at 1729 .

${ }^{36}$ Id. at 1739.

${ }^{37}$ Id. at 1743.

${ }^{88}$ Id. at 1750 .

${ }^{39}$ Id. at 1749.

${ }^{40}$ Joseph L. Smith \& Emerson H. Tiller, The Strategy of Judging: Evidence from Administrative Law, 31 J. LEGAL STUD. (forthcoming 2002) (on file with author).

${ }^{4}$ Id. (manuscript at 5-6). 
review the appellate panel decisions reversing the agency when they were based on process. ${ }^{42}$ Thus, a panel wanting to protect its reversal decision would choose process as a means to reverse over statutory interpretation. $^{49}$ The study examined all cases from 1981 through 1993 with published opinions by federal circuit courts in which the court reviewed the merits of a challenge to EPA action. ${ }^{44}$ The findings were statistically significant and consistent with the predictions of the resource-based strategy model. ${ }^{45}$ Democratic panels, when reversing the EPA, were more likely to use process reversals in favor of environmentalist challenges than when they were reversing in favor of industry (as compared with Republican panels). ${ }^{46}$ In contrast, Republican panels reversing the EPA were more likely to use process reversals in favor of industry challenges than when they were reversing in favor of environmentalists (as compared with Democratic panels). ${ }^{47}$ In short, the findings demonstrated that not only is process a means to control agency policy, it also could be a strategic choice by appellate courts wishing to make their policy survive higher court review. ${ }^{48}$

\section{HORIZONTAL RESOURCE-BASED STRATEGIES}

Resource-based strategies by one institution can be aimed at another institution in a manner that does not fit as neatly as in the hierarchy scenarios described above. For example, one horizontal resource-based strategy is for one institution to lower the decision costs of another like-minded institution as a way to exercise more control over a third institution. In this context, Professor Spiller and I modeled the ability of Congress to lower the costs for courts in reviewing agency action. ${ }^{49}$ We argued that through increasing judgeships, granting more money to the judiciary for clerks and other assistance, and legislatively changing statutory review standards for courts, Congress could make it easier for courts to review and reverse agencies when they disfavored the agencies' policies. ${ }^{50}$

In the horizontal resource-based context, Professor Spiller and I

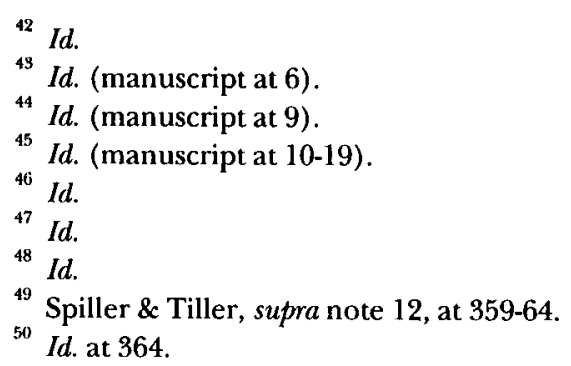


reviewed the proposed "Bumpers Amendments" of the early 1980s:

Those proposed amendments to the Administrative Procedures Act (APA) ${ }^{51}$ would have directed federal courts to decide all questions of law "de novo" (independently) and not to grant any "presumption of validity" to administrative rules set by regulators. The amendments would have allowed courts to consider agency interpretations of their duties under a statute but would not permit a court to presume that the interpretation of any agency was correct. ${ }^{52}$

The decision cost imposed varies depending on the reviewing court's policy preferences. For courts likely to disfavor agency policy, the amendments would decrease decision cost for them in achieving their goal-reversal of agency policy. The reason is that they would no longer need to spend decision resources to overcome the longstanding norm of deference established by the Supreme Court years earlier. For courts that favored the agency policy, decision costs increased for reaching their goal-upholding the agency policy. This occurred because the norm of deference (i.e., low decision cost for a court wishing to affirm agency) was now lost to a more costly statutory requirement of full de novo review. As Professor Spiller and I have observed:

The political context of the early 1980s helps explain why the proposed amendment was so popular, and controversial. Reagan had just entered office and was appointing regulators bent on reversing the tide of liberal regulation. The federal courts, however, were filled with liberal Democratic appointees, a group that many members of Congress could count on to guard against excessive deregulation efforts of Reagan-appointed regulators. The Bumpers Amendments would have reduced the decision costs of liberal federal judges by eliminating the norm (or doctrine) of judicial deference, thereby making reversal of agency policies more easily [accomplished by liberal judges].... The result would be that agencies would have less discretion to engage in deregulation.

${ }^{51} 5$ U.S.C. $\$ \$ 551-559$ (1994).

${ }^{52}$ Spiller \& Tiller, supra note 12, at 363 . In 1975, Senator Dale Bumpers (D-Ark.) introduced the first of these types of amendments to the APA. S. 2408, 94th Cong. (1975); see also 121 CONG. REC. 29,956 (1975) (statement of Sen. Bumpers) (discussing the amendments). Since that time, a variety of similar amendments generally attempting to tighten judicial review of agency actions have been called "Bumpers Amendments." See Ronald Levin, Review of "Jurisdictional" Issues Under the Bumpers Amendment, 1983 DUKE L.J. 355, 358-66 (discussing the legislative history of the Bumpers Amendments).

${ }^{53}$ Spiller \& Tiller, supra note 12 , at 363. 


\section{NEW DIMENSIONS IN PPT RESOURCE-BASED THEORY: RESOURCE-BASED STATUTES AND REGULATORY TARGETS AS RESOURCE STRATEGIZERS}

Jason Johnston's analysis of cost-benefit regulation adds a new layer of complexity, and reality, to the PPT models of resource-based strategies. ${ }^{54}$ Two important insights he brings are: (1) the differential resource effects on policy players from the various types of regulation that may be imposed on agencies (i.e., benefits statutes, procedural cost-benefit statutes, and substantive cost-benefit statutes), and (2) the introduction of regulated targets as resource strategizers. While Johnston incorporates these dimensions into a game with a nonideological judiciary, this Article suggests how his insights might operate in a game where the judiciary, as with the other actors in the regulatory game, is policy-seeking.

Consider that Congress is ever mindful of the judiciary's role in policing administrative agencies and that it designs many of the rules that govern judicial review of agency behavior. Congress controls the size of the judiciary, participates in filling judgeship positions, and controls much of the judiciary's budget. Research has shown that each of these powers can be used to exercise partisan or ideological control over the judiciary. ${ }^{55}$ And many studies suggest Congress would want to exercise that control given the judiciary's frequent policyseeking behavior. ${ }^{56}$ Congress can view the judiciary as a politically aligned ally in the control of agencies or it may view the judiciary as a politically unaligned, unreliable enforcement institution over agency

${ }^{54}$ See Jason Scott Johnston, A Game Theoretic Analysis of Alternative Institutions for Regulatory Cost-Benefit Analysis, 150 U. PA. L. REV. 1343, 1350 (2002) (using "the tools of game theory to model how regulatory decision making is likely to vary both with statutory type-whether the statute explicitly requires cost-benefit analysis-and with the substantive expertise and procedural openness of OMB review").

${ }^{55}$ See de Figueiredo et al., supra note 3 (considering political and ideological effects of congressional decisions to increase the number of federal judges); de Figueiredo \& Tiller, supra note 3, at 435 (examining congressional efforts to control the judiciary through controlling the number of federal judgeships); Eugenia F. Toma, A Contractual Model of the Voting Behavior of the Supreme Court: The Role of the Chief Justice, 16 INT'L REV. L. \& ECON. 433 (1996) (analyzing the role of the Chief Justice as an agent of Congress who reacts to budgeting signals sent by Congress); Eugenia F. Toma, Congressional Influence and the Supreme Court: The Budget as a Signaling Device, $20 \mathrm{~J}$. LEGAL STUD. 131, 134-35 (1991) (arguing that congressional budgetary largesse for the Supreme Court correlates with enthusiasm for its decisions).

${ }^{56}$ See, e.g., Daniel R. Pinello, Linking Party to Judicial Ideology in American Courts: A Meta-Analysis, 20 JUST. SYS. J. 219 (1999) (analyzing over eighty studies linking partisan affiliation with judicial behavior and concluding that party dependably indicates judicial ideology). 
behavior. How Congress views the judiciary should affect what type of benefits or cost-benefit statutes Congress will impose, if any at all.

To illustrate some of the new insights in brief fashion, I will make some simplifying (overly simplifying) assumptions and pose a highly stylized analysis. Let us suppose that Congress considers three other players in the regulatory game: the Agency (A), the Judiciary $(\mathrm{J})$, and the regulatory Targets $(\mathrm{T})$. Let "+" represent alignment with Congress and "-" nonalignment such that there are eight alignment permutations: ${ }^{57}$

$\left(\mathrm{A}^{+}, \mathrm{J}^{*}, \mathrm{~T}^{+}\right)=$Agency, Judiciary, and Targets aligned with Congress

$\left(\mathrm{A}^{+}, \mathrm{J}^{-}, \mathrm{T}^{-}\right)=$Agency aligned, Judiciary and Targets not aligned with Congress

$\left(\mathrm{A}^{-}, \mathrm{J}^{*}, \mathrm{~T}^{*}\right)=$ Agency not aligned, Judiciary and Targets aligned with Congress

$\left(\mathrm{A}^{-}, \mathrm{J}^{-}, \mathrm{T}^{-}\right)=$Agency, Judiciary, and Targets not aligned with Congress

$\left(\mathrm{A}^{+}, \mathrm{J}^{+}, \mathrm{T}^{-}\right)=$Agency and Judiciary aligned, Targets not aligned with Congress

$\left(\mathrm{A}^{+}, \mathrm{J}^{-}, \mathrm{T}^{+}\right)=$Agency and Target aligned, Judiciary not aligned with Congress

$\left(\mathrm{A}^{-}, \mathrm{J}^{+}, \mathrm{T}^{-}\right)=$Agency and Target not aligned, Judiciary aligned with Congress

$\left(A^{-}, J^{-}, T^{+}\right)=$Agency and Judiciary not aligned, Targets aligned with Congress

There are four types of regulatory statutes we can envision for this analysis: two benefits types and two cost-benefit types. The two types of cost-benefit statutes that Johnston models are procedural and substantive cost-benefit statutes. ${ }^{58}$ According to Johnston, under a substantive cost-benefit statute "the agency is explicitly instructed to balance the costs and benefits of alternative standards for reducing ... risk[], and to set the standard at a 'reasonable' level."59 In contrast, procedural cost-benefit statutes "say nothing about how the agency strikes the cost-benefit balance; they merely require the agency to do the balancing." ${ }^{60}$ Johnston, although he analyzes them as one type, also models benefits statutes. ${ }^{61}$

For my purposes, I dimensionalize the benefits statutes as two types: optional benefits and mandatory benefits statutes. The op-

${ }^{57}$ The notation is for ease of exposition and tracking by the reader, and not for modeling a formal result here.

${ }^{58}$ See Johnston, supra note 54, at 1350 ("In this Article, I address these gaps in the literature by using the tools of game theory to model how regulatory decision making is likely to vary both with statutory type ... and with the substantive expertise and procedural openness of OMB review.").

${ }^{59}$ Id. at 1351 .

Id. at 1352.

${ }^{61}$ Id. at $1363-70$. 
tional benefits statute is one that gives an agency the right to impose regulation on targets at the agency's discretion; ${ }^{62}$ the mandatory benefits statute is one that requires the agency to produce regulation (perhaps with a "hammer" provision if the agency fails to act, or through special standing for groups and individuals to challenge agency inaction in court). Consider several of the following scenarios to illustrate the choices before Congress.

\section{A. Congress and Targets Aligned}

For all cases where the targets are aligned with Congress $\left(\mathrm{T}^{+}\right)$, Congress would want to encourage little, if any, regulation by the agency. If the agency is also aligned with Congress $\left(\mathrm{A}^{+}, \mathrm{T}^{+}\right)$, then there is no need to control the agency, as it will likewise protect the targets from any costly regulation. Under such conditions, there should be few, if any, legislative mandates on the agency. If, however, the agency is not aligned with Congress while the targets are so aligned $\left(\mathrm{A}^{-}, \mathrm{T}^{+}\right)$, then Congress may contemplate imposing resource demands upon the agency if the agency is likely to proceed with the regulation. If the judiciary is aligned with Congress $\left(\mathrm{A}^{-}, \mathrm{J}^{+}, \mathrm{T}^{+}\right)$, then a cost-benefit statute would bring value to Congress as the courts could be expected to enforce the resource expenditures upon the agency when the agency attempts to regulate. In this sense, the courts are working with Congress to impose costs on the agency.

The legislative choice between procedural and substantive costbenefit would also come into play in these situations. If we assume (1) substantive cost-benefit analysis demands more resources of an agency than procedural cost-benefit analysis, and (2) that substantive cost-benefit analysis makes it easier for courts to reverse agencies (that is, courts can use fewer of their own resources in overturning an agency) ${ }^{69}$ then a substantive cost-benefit statute would be the optimal legislative choice. If the judiciary is not aligned with Congress $\left(\mathrm{A}^{-}, \mathrm{J}^{-}\right.$, $\mathrm{T}^{+}$), then the picture is less clear. It may be that Congress decides not to impose any cost-benefit statute because enforcement would not be

62 According to Johnston, under benefits statutes an agency is only directed to consider gross, not net, regulatory benefits. Id. at 1350-51.

${ }^{63}$ The logic here is that courts have limited tools to find flaws in agency reasoning processes and substantive cost-benefit analysis provides more opportunity for the courts to find such flaws and exercise control over an agency. If the court were reviewing under a procedural cost-benefit mandate, it would need to work harder to find flaws to justify its reversal of the agency (or perhaps risk some reputational costs for a weakly reasoned decision of its own to reverse the agency). 
reliable. Or it may be that cost-benefit statutes, on their own, have some power to constrain agency resources (and improve information communicated to Congress, allowing it to intervene selectively in agency process), irrespective of the judiciary's willingness to enforce those statutes.

\section{B. Congress and Targets Not Aligned}

Consider next the situation where the targets are not aligned with Congress $\left(\mathrm{T}^{-}\right)$. In this scenario, Congress generally would not want to constrain an agency's ability to regulate targets, but instead would want to facilitate or even require an agency to regulate the targets. If the agency is aligned with Congress $\left(\mathrm{A}^{+}, \mathrm{T}^{-}\right)$, then Congress will, at most, enable the agency to regulate the target through an optional benefits statute, if the agency's prior mandate did not allow for such regulation of the targets. If the judiciary is similarly aligned with Congress $\left(\mathrm{A}^{+}, \mathrm{J}^{+}, \mathrm{T}^{-}\right)$, then the agency will have little difficulty in effectuating regulation of the targets. If the courts are not aligned $\left(\mathrm{A}^{+}, \mathrm{J}^{-}, \mathrm{T}^{-}\right)$, then agency costs go up if they attempt to regulate the targets as courts will themselves impose costs on the agency though the prospect of process review. ${ }^{65}$ In such a scenario, Congress may be more inclined to give resources to the agency, or impose costs on the courts, to reduce the courts' ability to exercise resource-based control over agencies.

If the agency is not aligned with Congress $\left(\mathrm{A}^{-}, \mathrm{T}^{-}\right)$, then Congress will be more inclined towards a mandatory benefits statute. Whether the mandatory benefits statute uses a hammer provision or gives nontargets (interest groups and individuals) special standing to challenge agency inaction in the courts may depend on the alignment of the judiciary. If the judiciary is aligned $\left(\mathrm{A}^{-}, \mathrm{J}^{+}, \mathrm{T}^{-}\right)$, then giving special litigation rights to aligned interest groups and individuals will impose costs on an agency for inaction and will allow courts to play the enforcement role. If the courts are not aligned $\left(\mathrm{A}^{-}, \mathrm{J}^{-}, \mathrm{T}^{-}\right)$, then Congress may be more inclined to use a hammer provision in mandatory benefits statutes.

Note that in the scenario where Congress is not aligned with the

${ }^{64}$ The Unfunded Mandates Reform Act of 1995 is an example of Congress requiring agencies to comply with the results of their cost-benefit analysis, but eliminated judicial review. 2 U.S.C. $\$ \S 1532,1571(2000)$.

${ }^{65}$ Tiller, supra note 21, at 116-17 (explaining how courts, through powers granted under the APA, can impose costs on agencies in an effort to control agency policy). 
regulated targets, legislators generally still may wish to protect certain constituent targets from their own districts. This may give reason to use a procedural cost-benefit statute. Consider the case where the agency and courts are aligned with Congress $\left(\mathrm{A}^{+}, \mathrm{J}^{+}, \mathrm{T}^{-}\right)$, as mentioned above. Congress would not need to impose a benefits statute because the agency would be inclined to regulate the targets on its own (if such were within the general jurisdiction of the agency). At most, an optional benefits statute would be put in place to enable the agency to proceed. But if legislators wish to protect targets in their own districts, the aligned agency and judiciary cannot be expected to parcel out exceptions since they are not concerned about electoral needs. Thus, legislators may want to create an opportunity to selectively intervene in agency regulation behavior when a constituent target is at risk. A procedural cost-benefit statute may be useful as it interjects more process into the agency regulatory decision making and creates opportunity for legislator involvement. While a substantive cost-benefit statute may likewise create such an opportunity, it also increases agency decision costs more generally and may prevent regulation on targets that Congress would want regulated. As cost-benefit statutes go, procedural cost-benefit minimizes the resource constraint on the agency while enhancing selective control by individual legislators over agency decisions that touch the legislator's own constituency.

\section{Targets as Resource Strategizers}

Johnston reveals how targets become active players in a regulatory game by imposing costs on agencies through lobbying and litigation. ${ }^{66}$ His analysis depends somewhat on agencies and courts that are more politically neutral than the PPT approach I have described in this Article. Nonetheless, his view of a target as resource strategizer has special relevance in the more "political" versions of PPT. Consider the situation in which Congress and the targets are aligned against the courts and agency (which wishes to regulate): $\left(\mathrm{A}^{-}, \mathrm{J}^{-}, \mathrm{T}^{+}\right)$. Targets would concentrate more resources on lobbying than litigation, compared to a scenario where the courts were aligned with Congress and the targets, because courts could not be counted upon to resist an agency's regulation and Congress is sympathetic to targets. If the courts were aligned with the targets $\left(\mathrm{A}^{-}, \mathrm{J}^{+}, \mathrm{T}^{+}\right)$, then courts would be more inclined to protect the targets when targets litigate; thus, we

${ }^{60}$ See Johnston, supra note 54, at 1350 (explaining that regulatory targets "have two opportunities to block regulation": lobbying and judicial review). 
would expect targets to shift more resources to litigation when aligned with courts. Assuming that Congress is also aligned with the courts and targets, it can facilitate such resource allocation by targets toward the courts by imposing substantive cost-benefit statutes. These would encourage the targets to spend resources on the agency process (to set up a minefield for later judicial challenge) and to spend resources directly on litigation.

Since agencies know that these expected resource expenditures by targets would increase the resource expenditures of agencies, the agency, as Johnston points out, may reach equilibrium and reduce regulation before any litigation efforts are made. The agency's decision will be based in part on what it learns about the amount of cost a regulation will impose on a target. Johnston's regulation model shows that the agency usually will have an incentive to internalize some of the compliance costs its regulation will impose, because the higher the target's perceived cost of regulatory compliance, the greater its equilibrium expenditure on lobbyists and lawyers at both the lobbying and litigation stages. The greater the target's effort and expenditure in resisting regulation, the lower will be the agency's expected net return from promulgating the regulation. "As a consequence, among regulatory alternatives yielding an equal benefit as perceived by the regulator, the regulatory game itself provides an incentive for the regulator to choose the cost-minimizing alternative." ${ }^{\text {"67 }}$

Targets may need to spend resources lobbying Congress or participating in agency processes (producing studies of costs on targets, proposing alternatives, and the like) to signal the agency that they are willing to go the final step in the resource battle and litigate. If targets do not participate in the cost-benefit analysis at the agency level, the value of substantive cost-benefit statutes for litigation purposes may be lost. If neither the courts nor the agency is aligned with targets $\left(\mathrm{A}^{-}, \mathrm{J}^{-}\right.$, $\mathrm{T}^{+}$), then the targets' resource allocation may be directed more at lobbying and seeking legislator intervention into the regulatory process.

\section{CONCLUSION}

There are of course many other alternative strategies for the players in the game described above depending on the actual resources the institutions hold, as well as the comparative costs of available

\footnotetext{
${ }^{67}$ Id. at 1353.
} 
strategies. Without more empirical work on agency, court, and target resources, we will not know how these resource incentives precisely play out in reality. We also need to explore more thoroughly the relationship between legislators and their constituent targets in the resource-based game. But the PPT framework suggested above, with a politically active court, illustrates that Congress can expect differential resource impacts from different regulatory statutes. Depending on the alignment, or nonalignment, of the agency and judiciary with Congress, legislators will be selective in what types of regulatory statutes they will pass to foster their policy agenda and, if needed, control of agencies. Targets as resource strategizers are part of the legislative decision as the design of legislation can allow targets to police agency behavior, whether through lobbying, agency process, or litigation. Dimensionalizing cost-benefit statutes and viewing targets as resource strategizers pushes us to another, fruitful level of analysis in congressional control of agencies and' regulation. For a more complete Positive Political Theory of resource-based strategizing, however, similar extensions must be pursued regarding the broader set of resourcebased control instruments exercised by Congress, agencies, and the courts. 